\title{
Synthesis and X-Ray Crystal Structure Determination of Thiotrithiazyl Iododichloride, $\mathrm{S}_{\mathbf{4}} \mathrm{N}_{3} \mathrm{ICl}_{2}$
}

Stephan H. Irsen and Richard Dronskowski

Institut für Anorganische Chemie der RWTH Aachen, Prof.-Pirlet-Str. 1, D-52056 Aachen

Reprint requests to Prof. Dr. R. Dronskowski. E-mail: drons@HAL9000.ac.rwth-aachen.de

Dedicated to Professor Albrecht Mewis on the occasion of his 60th birthday

Z. Naturforsch. 57 b, 1387-1390 (2002); received November 20, 2002

Thiotrithiazyl Iododichloride, Tetrasulfur Tetranitride, Rietveld Refinement

Thiotrithiazyl iododichloride, $\mathrm{S}_{4} \mathrm{~N}_{3} \mathrm{ICl}_{2}$, has been synthesized from molecular $\mathrm{S}_{4} \mathrm{~N}_{4}$ and liquid $\mathrm{ICl}$ and structurally characterized by an X-ray Rietveld refinement. $\mathrm{S}_{4} \mathrm{~N}_{3} \mathrm{ICl}_{2}$ crystallizes in the monoclinic system $\left(P 2_{1} / c, a=611.548(7), b=877.336(8), c=1770.12(2) \mathrm{pm}, \beta=\right.$ $\left.92.3357(7)^{\circ}, Z=4\right)$, follows the crystal-chemical motif $\left(\mathrm{S}_{4} \mathrm{~N}_{3}^{+}\right)\left(\mathrm{ClCl}^{-}\right)$, and is thus isotypic with $\left(\mathrm{S}_{4} \mathrm{~N}_{3}^{+}\right)\left(\mathrm{Br}_{3}^{-}\right)$. The crystal structure contains a planar $\mathrm{S}_{4} \mathrm{~N}_{3}^{+}$ring and a linear $\mathrm{ClICl}^{-}$unit.

\section{Introduction}

Polysulfurnitride, $(\mathrm{SN})_{x}$, has been the first example of an artificial metal of polymeric nature composed purely of nonmetallic main group elements. It was first described almost a century ago [1] but the belated discovery of $(\mathrm{SN})_{x}$ 's superconductivity in the 1970s quickly boosted an interest in the chemistry of $\mathrm{S} / \mathrm{N}$-containing molecules such as tetrasulfur tetranitride, $\mathrm{S}_{4} \mathrm{~N}_{4}$, and its halogenated derivatives. While the chemistry and the physical properties of $(\mathrm{SN})_{x}$ are extensively covered in the scientific literature $[2,3]$, our general knowledge concerning, for example, the structure of the brominated phase as well as other reaction products of various sulfur nitrides in combination with the halogens is far from being complete.

In 1977, Street et al. communicated [4] a reaction between $\mathrm{S}_{4} \mathrm{~N}_{4}$ and bromine vapor that led to a metallically conducting solid which was similar in physical properties to the brominated derivatives of $(\mathrm{SN})_{x}$. Shortly after, these reactions were extended by using related molecular educts, and they yielded similar conducting materials $[5,6]$. It is worth mentioning that the corresponding reaction of $\mathrm{S}_{4} \mathrm{~N}_{4}$ in liquid bromine, in contrast, gives access to a salt-like compound, namely $\mathrm{S}_{4} \mathrm{~N}_{3} \mathrm{Br}_{3}$ (三 $\left.\left(\mathrm{S}_{4} \mathrm{~N}_{3}^{+}\right)\left(\mathrm{Br}_{3}^{-}\right)\right)$, the crystal structure of which was first published [7] in 1979. In that particular paper, the authors mentioned the corresponding reaction between $\mathrm{S}_{4} \mathrm{~N}_{4}$ and ICl but did not offer any struc- tural details for the product. This was the starting point of our investigation.

In the course of our systematic studies on the temperature-dependent crystal structures [8] and chemical reactivity [9] of tetrasulfur tetranitride, we have reinvestigated the above mentioned reaction starting from $\mathrm{S}_{4} \mathrm{~N}_{4}$ and liquid ICl. Here we report in detail about the synthesis and $\mathrm{X}$-ray crystal structure analysis (Rietveld technique) of $\mathrm{S}_{4} \mathrm{~N}_{3} \mathrm{ICl}_{2}$.

\section{Experimental Section}

\subsection{Synthesis}

The title compound was made from crystalline $\mathrm{S}_{4} \mathrm{~N}_{4}$ and ICl. ICl itself was prepared from the elements according to the procedure by Brauer [10]. In order to obtain a well-crystallized and pure single-phase product, all synthetic steps were carried out in an inert atmosphere of argon. At the beginning, $92 \mathrm{mg}(0.5 \mathrm{mmol})$ of $\mathrm{S}_{4} \mathrm{~N}_{4}$ was very carefully [11] powdered in an agate mortar. The powder was then mixed with an excess $(\approx 5 \mathrm{ml})$ of freshly made $\mathrm{ICl}$ and sealed into a glass ampoule. The reaction mixture was heated to $80^{\circ} \mathrm{C}$ for a period of $4 \mathrm{~d}$. After that, excess $\mathrm{ICl}$ was distilled away in a vacuum, and the crude product of dark-red color was dried by evacuating the material a second time somewhat above room temperature. The final yield was $87 \mathrm{mg}$ of a yellow material.

\subsection{Structure determination}

Since all selected crystals of $\mathrm{S}_{4} \mathrm{~N}_{3} \mathrm{ICl}_{2}$ turned out to be extremely soft and unsuitable (too strongly twinned or too small) for a single-crystal structure determination, a small 
Table 1. Crystallographic Data of $\mathrm{S}_{4} \mathrm{~N}_{3} \mathrm{ICl}_{2}$.

\begin{tabular}{ll}
\hline Formula & $\mathrm{S}_{4} \mathrm{~N}_{3} \mathrm{ICl}_{2}$ \\
Molecular weight & $368.09 \mathrm{~g} / \mathrm{mol}$ \\
Lattice parameters & $a=611.548(7), b=877.336(8)$, \\
& $c=1770.12(2) \mathrm{pm}, \beta=92.3357(7)^{\circ}$ \\
Space group & $P 2_{1} / c(\mathrm{Nr} .14)$ \\
Formula units & 4 \\
X-ray density & $2.576 \mathrm{~g} / \mathrm{cm}^{3}$ \\
Absorption coefficient & $39.45 \mathrm{~mm}^{-1}$ \\
Sample dimension & flat sample \\
Instrument & Stoe STADI powder diffractometer, \\
& Cu-K $\alpha_{1}$ rad., Ge monochromator, \\
& linear proportional counter \\
Scan type; range; step & $2 \theta ; 10.00^{\circ} \leq 2 \theta \leq 89.99^{\circ} ; 0.01^{\circ}$ \\
Scan speed & $100 \mathrm{~s} / \mathrm{step}$ \\
Temperature & $293(1) \mathrm{K}$ \\
Data points & 8000 \\
Bragg reflections & 761 \\
Background & manual \& Fourier filtering \\
Structure refinement & Rietveld least-squares method \\
Profile function & pseudo-Voigt \\
$\eta, X$ mixing params & $0.41(2),-0.0042(5)$ \\
$u, v, w$ halfwidth param. & $0.044(3),-0.023(2), 0.0172(3)$ \\
Preferred orient. function & March-Dollase, $G=0.869(1)$ \\
Variables; constraints & 45,3 \\
Zero point & $-0.0109(3)$ \\
$R_{\mathrm{p}} ; R_{\mathrm{wp}}$ & $0.021 ; 0.028$ \\
$R$ Bragg $(I) ;$ GooF & $0.057 ; 1.57$ \\
$S_{\text {corr }}$ & 3.86 \\
\hline & \\
&
\end{tabular}

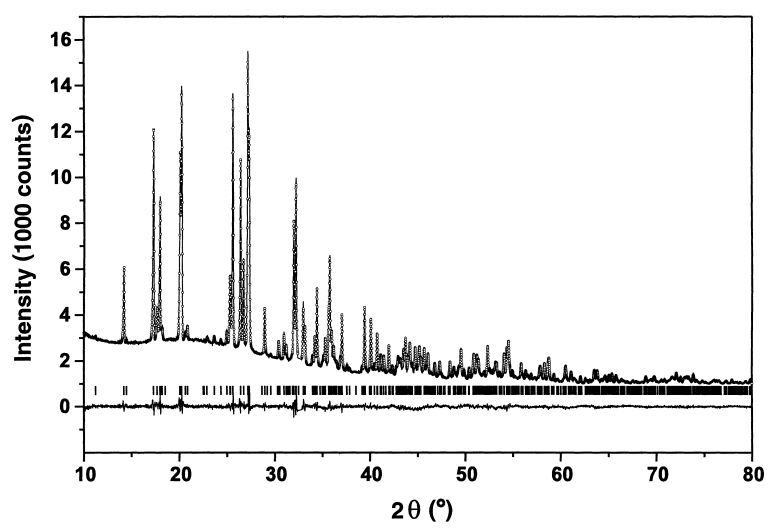

Fig. 1. Rietveld refinement of $\mathrm{S}_{4} \mathrm{~N}_{3} \mathrm{ICl}_{2}$; depicted are measured (circles) and calculated (line) diffraction patterns, the positions of the Bragg peaks, and the difference between observed and calculated intensities.

amount (about $10 \mathrm{mg}$ ) of the yellow substance was finely powdered, fixed between two rubberized Kapton foils (Dupont) and prepared as a flat sample for X-ray powder investigations. The diffraction pattern was recorded between $10.00-89.99^{\circ}$ in $2 \theta$ using a Debye-Scherrer powder diffractometer (Stoe STADI), monochromatized
Table 2. Positional parameters (all atoms on Wyckoff position $4 e$ ) and isotropic displacement parameters of $\mathrm{S}_{4} \mathrm{~N}_{3} \mathrm{ICl}_{2}$. Sulfur, nitrogen and halogen atoms were grouped using common displacement parameters during the refinement.

\begin{tabular}{llllc}
\hline Atom & \multicolumn{1}{c}{$x$} & \multicolumn{1}{c}{$y$} & \multicolumn{1}{c}{$z$} & $B_{\text {iso }}\left(\AA^{2}\right)$ \\
\hline $\mathrm{S}(1)$ & $0.4777(8)$ & $0.8389(4)$ & $0.1860(3)$ & $3.20(6)$ \\
$\mathrm{S}(2)$ & $0.2148(7)$ & $0.7409(4)$ & $0.2417(3)$ &, \\
$\mathrm{S}(3)$ & $0.9968(8)$ & $0.6060(5)$ & $0.1040(3)$ &, \\
$\mathrm{S}(4)$ & $0.3671(8)$ & $0.7464(4)$ & $0.0290(3)$ &, \\
$\mathrm{N}(1)$ & $0.461(2)$ & $0.825(1)$ & $0.0945(7)$ & $2.0(2)$ \\
$\mathrm{N}(2)$ & $0.052(2)$ & $0.645(1)$ & $0.1847(8)$ &, \\
$\mathrm{N}(3)$ & $0.135(2)$ & $0.639(1)$ & $0.0445(7)$ & $"$ \\
$\mathrm{I}$ & $0.2215(2)$ & $0.2101(1)$ & $0.12489(9)$ & $4.07(3)$ \\
$\mathrm{Cl}(1)$ & $0.5123(8)$ & $0.4329(4)$ & $0.1444(2)$ &, \\
$\mathrm{Cl}(2)$ & $0.9468(7)$ & $0.0004(3)$ & $0.1068(3)$ & $"$ \\
\hline
\end{tabular}

$\mathrm{Cu}-\mathrm{K}_{\alpha_{1}}$ radiation (focusing germanium monochromator), and a linear proportional counter.

Twenty sharp reflections with high intensities were selected from the data set to determine the lattice parameters of $\mathrm{S}_{4} \mathrm{~N}_{3} \mathrm{ICl}_{2}$. Unfortunately, all available indexing algorithms failed such that no reasonable lattice could be obtained. Hence we continued the structure calculations using the previously published [7] lattice parameters of $\mathrm{S}_{4} \mathrm{~N}_{3} \mathrm{Br}_{3}(a=610.5, b=879.2, c=1806 \mathrm{pm}$, $\beta=91.58^{\circ}$ ) because Street et al. [5] predicted $\mathrm{S}_{4} \mathrm{~N}_{3} \mathrm{ICl}_{2}$ to be isotypic with $\mathrm{S}_{4} \mathrm{~N}_{3} \mathrm{Br}_{3}$. These four lattice parameters were then varied in a stepwise manner using the POWDERCELL program [12] to fit the measured reflections of $\mathrm{S}_{4} \mathrm{~N}_{3} \mathrm{ICl}_{2}$ as closely as possible. The result of this procedure $\left(a=608, b=872, c=1761 \mathrm{pm}, \beta=92.3^{\circ}\right)$ was subsequently used as an input for the Rietveld profile refinement of the whole pattern using the FULLPROF package [13].

The background of the data set was first manually subtracted by linear interpolation and afterwards smoothed by linear, nonrecursive filtering in the last refinement cycle (1\% filter width of all data points). The data were refined in the monoclinic space group $P 2_{1} / c$, and the atomic positions were taken from the crystal structure of $\mathrm{S}_{4} \mathrm{~N}_{3} \mathrm{Br}_{3}$ [7]. An overview of the refinement is given in Fig. 1 while all important numerical details may be found in Table 1. Positional as well as isotropic displacement factors are listed in Table 2. All standard deviations need to be multiplied with the parameter $S_{\text {corr }}$ for possible comparison with single crystal results $[14]^{*}$.

${ }^{*}$ A list of the observed and calculated X-ray intensities can be obtained from either Fachinformationszentrum Karlsruhe, D-76344 Eggenstein-Leopoldshafen (Germany), by quoting the registry number CSD-412 782, or directly from R. D. 

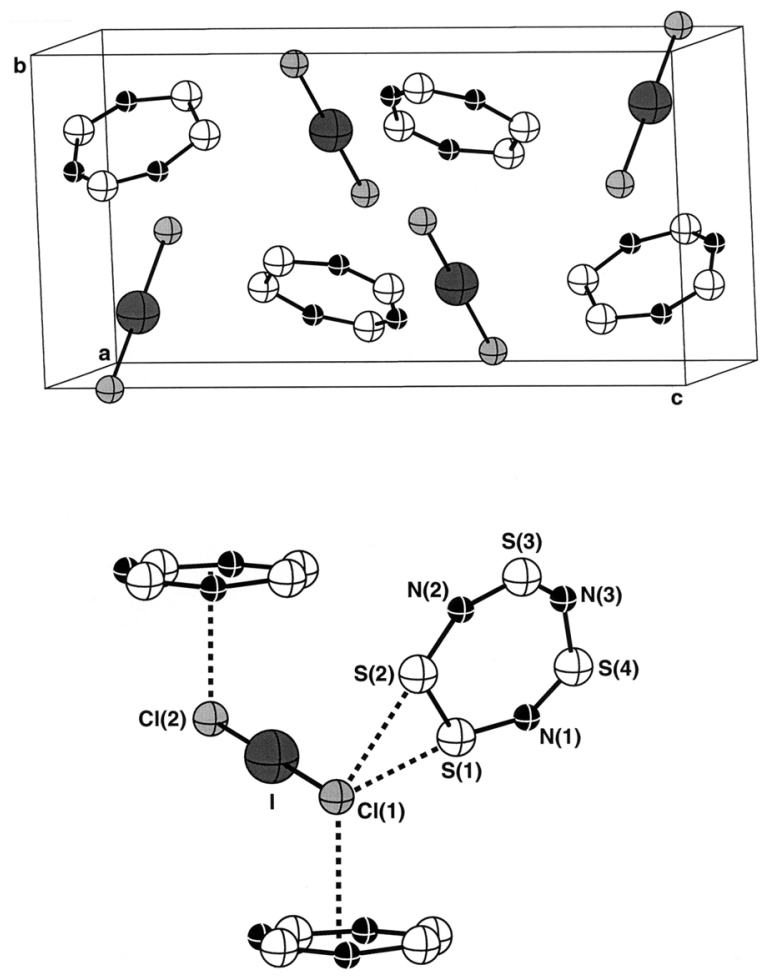

Fig. 2. Top: Packing of cations and anions in the crystal structure of $\mathrm{S}_{4} \mathrm{~N}_{3} \mathrm{ICl}_{2}$. S, N, I, and $\mathrm{Cl}$ atoms are given as open, black, dark- and light-grey balls. Bottom: Coordination motifs in $\mathrm{S}_{4} \mathrm{~N}_{3} \mathrm{ICl}_{2}$.

\section{Results and Discussion}

Fig. 2 offers a view of the crystal structure and the coordinations of $\mathrm{S}_{4} \mathrm{~N}_{3} \mathrm{ICl}_{2}$ while all important bond lengths and angles are given in Table 3.

There are four formula units per unit cell, and the structural motif is made up from planar $\mathrm{S}_{4} \mathrm{~N}_{3}^{+}$ rings together with $\mathrm{ClCl}^{-}$units. The alternating stacks of cations and anions are packed along the $b$ axis. Within the $\mathrm{S}_{4} \mathrm{~N}_{3}^{+}$ring, the intramolecular $\mathrm{S}-\mathrm{N}$ distances scatter around an average (and quite typical [15]) value of $c a .156 \mathrm{pm}$. The larger spectrum for the bond lengths involving the lightest atom $(\mathrm{N})$ simply reflects the limited resolution of the powder refinement and should not be overinterpreted. On the other side, the average $\mathrm{S}-\mathrm{N}$ bond length of $156 \mathrm{pm}$ is roughly $6 \mathrm{pm}$ shorter than within molecular $\mathrm{S}_{4} \mathrm{~N}_{4}$ and $18 \mathrm{pm}$ shorter than the sum of the covalent radii of $\mathrm{S}$ and $\mathrm{N}$ [16]. The one $\mathrm{S}-\mathrm{S}$ bond
Table 3. Important bond lengths (pm) and angles $\left(^{\circ}\right)$ of $\mathrm{S}_{4} \mathrm{~N}_{3} \mathrm{ICl}_{2}$.

\begin{tabular}{lllr}
\hline $\mathrm{S}(1)-\mathrm{N}(1)$ & $162(1)$ & $\mathrm{S}(1)-\mathrm{S}(2)-\mathrm{N}(2)$ & $112.4(6)$ \\
$\mathrm{S}(1)-\mathrm{S}(2)$ & $210.4(7)$ & $\mathrm{S}(2)-\mathrm{N}(2)-\mathrm{S}(3)$ & $145.3(9)$ \\
$\mathrm{S}(2)-\mathrm{N}(2)$ & $162(1)$ & $\mathrm{N}(2)-\mathrm{S}(3)-\mathrm{N}(3)$ & $123.3(7)$ \\
$\mathrm{S}(3)-\mathrm{N}(2)$ & $149(2)$ & $\mathrm{S}(3)-\mathrm{N}(3)-\mathrm{S}(4)$ & $138.6(8)$ \\
$\mathrm{S}(3)-\mathrm{N}(3)$ & $141(1)$ & $\mathrm{N}(3)-\mathrm{S}(4)-\mathrm{N}(1)$ & $115.6(7)$ \\
$\mathrm{S}(4)-\mathrm{N}(1)$ & $145(1)$ & $\mathrm{S}(4)-\mathrm{N}(1)-\mathrm{S}(1)$ & $147.3(8)$ \\
$\mathrm{S}(4)-\mathrm{N}(3)$ & $174(1)$ & $\mathrm{N}(1)-\mathrm{S}(1)-\mathrm{S}(2)$ & $114.8(5)$ \\
$\mathrm{S}(1)-\mathrm{Cl}(1)$ & $311.2(6)$ & $\mathrm{I}-\mathrm{Cl}(1)-\mathrm{S}(1)$ & $85.2(1)$ \\
$\mathrm{S}(2)-\mathrm{Cl}(1)$ & $306.8(6)$ & $\mathrm{I}-\mathrm{Cl}(1)-\mathrm{S}(2)$ & $91.4(1)$ \\
$\mathrm{I}-\mathrm{Cl}(1)$ & $265.6(4)$ & $\mathrm{Cl}(1)-\mathrm{I}-\mathrm{Cl}(2)$ & $179.8(5)$ \\
$\mathrm{I}-\mathrm{Cl}(2)$ & $250.3(4)$ & & \\
\hline
\end{tabular}

is $210 \mathrm{pm}$, i.e., a regular single bond taking into account the covalent radius of S (104 pm) [16].

The anionic unit $\mathrm{ClICl}^{-}$is linear within instrumental resolution. The two $\mathrm{I}-\mathrm{Cl}$ bonds are indeed different (250 and $266 \mathrm{pm}$ ), a result which certainly goes back to their differing coordinations. While the $\mathrm{Cl}(1)$ atom exhibits two contacts (307 and $311 \mathrm{pm}$ ) to the $S(2)$ and $S(1)$ atoms (that is, more than 50 pm shorter than the sum of the van-der-Waals radii [16]), the distances between $\mathrm{Cl}(2)$ and the atoms of the cationic ring (more than $346 \mathrm{pm}$ ) are probably nonbonding. Mayerle and coworkers already exemplified [7] that within the asymmetric trihalides the terminal halogen atom involved in the longest bond $-\mathrm{Cl}(1)$ inside $\left(\mathrm{S}_{4} \mathrm{~N}_{3}^{+}\right)\left(\mathrm{ClICl}^{-}\right)$- is most closely surrounded by neighboring atoms. The orientation of cations and anions is not fully parallel; the $\mathrm{ClICl}^{-}$ unit is slightly canted $\left(13^{\circ}\right)$ with respect to the $\mathrm{S}_{4} \mathrm{~N}_{3}^{+}$ rings between which it is sandwiched.

It is interesting to note that the lattice parameters of $\mathrm{S}_{4} \mathrm{~N}_{3} \mathrm{ICl}_{2}$ compare astonishingly well with those of $\mathrm{S}_{4} \mathrm{~N}_{3} \mathrm{Br}_{3}$; in fact, only the $c$ axis is significantly $(2 \%)$ shorter for the title compound. The decrease in molecular volumes when going from $\mathrm{S}_{4} \mathrm{~N}_{3} \mathrm{Br}_{3}$ to $\mathrm{S}_{4} \mathrm{~N}_{3} \mathrm{ICl}_{2}$, however, is also a bit larger $\left(3 \mathrm{~cm}^{3} / \mathrm{mol}\right)$ than what would be expected based on tabulated [17] volume increments $\left(1 \mathrm{~cm}^{3} / \mathrm{mol}\right)$.

\section{Acknowledgements}

It is a pleasure to thank Dr. Jürgen Huster for having collected the X-ray powder data, Drs. Paul Müller, Peter Kroll and Bernhard Eck for computational assistance, and also the Deutsche Forschungsgemeinschaft as well as the Fonds der Chemischen Industrie for their continuous support. 
[1] F. P. Burt, J. Chem. Soc. 1171 (1910)

[2] M. M. Labes, P. Love, L. F. Nichols, Chem. Rev. 79, 1 (1979).

[3] J. M. Rawson, J. L. Longridge, Chem. Soc. Rev. 26, 53 (1997).

[4] G. B. Street, R. L. Bingham, J. I. Crowley, J. Kuyper, J. Chem. Soc. Chem. Commun. 464 (1977).

[5] G. Wolmershäuser, G. B. Street, Inorg. Chem. 17, 2685 (1978).

[6] A. J. Banister, N. R. M. Smith, J. Chem. Soc. Dalton Trans. 937 (1980).

[7] J. J. Mayerle, G. Wolmershäuser, G. B. Street, Inorg. Chem. 18, 1161 (1979).

[8] S. H. Irsen, P. Jacobs, R. Dronskowski, Z. Anorg. Allg. Chem. 627, 321 (2001).

[9] S. H. Irsen, P. Kroll, R. Dronskowski, Th. E. Weirich, M. Epple, Z. Anorg. Allg. Chem., submitted.
[10] G. Brauer, Handbuch der Präparativen Anorganischen Chemie, 3rd edition, Ferdinand Enke Verlag, Stuttgart (1981).

[11] Caution! $\mathrm{S}_{4} \mathrm{~N}_{4}$ is a highly explosive material and extremely sensitive against both mechanical as well as thermal stress.

[12] W. Kraus, G. Holze, Powdercell: Ein Computerprogramm zur Simulation von Pulverdiffraktogrammen, BAM Berlin (1999).

[13] J. Rodriguez-Carvajal, Fullprof, Laboratoire Léon Brillouin (2000).

[14] J.-F. Bérar, P. Lelann, J. Appl. Crystallogr. 24, 1 (1990).

[15] N. N. Greenwood, A. Earnshaw, Chemistry of the Elements, 1st edition, Pergamon Press (1986).

[16] J. Emsley, The Elements, 2nd edition, Oxford University Press, Oxford (1995).

[17] W. Biltz, Raumchemie der festen Stoffe, Verlag von Leopold Voss, Leipzig (1934). 